UDC $327(485+480)$

Submitted: 17.07.2018

LBC 66.4(41)

Accepted: 21.10 .2018

\title{
POLITICAL DISCUSSIONS ON ADMISSION OF NEUTRAL COUNTRIES OF THE ARCTIC REGION TO NATO IN THE 1990s-2000s: INCLUSION OR A LIMITED NEUTRALITY?
}

\author{
Slavyana Yu. Boldyreva \\ Northern (Arctic) Federal University named after M.V. Lomonosov, \\ Arkhangelsk, Russian Federation \\ Roman Yu. Boldyrev \\ Northern (Arctic) Federal University named after M.V. Lomonosov, \\ Arkhangelsk, Russian Federation
}

\begin{abstract}
Introduction. Sweden and Finland obtain a special position within NATO strategy towards neutral states. The purpose of the paper is to analyze the background and perspectives for Sweden and Finland to join NATO in the 1990s - 2000s. This issue appeared on the top of agenda after these countries had entered the EU, and right after the Baltic states became members of NATO.

Finland started to distant itself from Russia in 1990-1992, right after recognizing itself free from military and technical limitations set in the Peace treaty signed in 1947 and gaining an ability to arrange political and military alliances with other countries. Joining the Alliance has first appeared on the Finnish political agenda in the first half of the 1990s, though the political elite of Finland defining its practical relations with NATO also took into consideration the position of Russia since both countries had a long joint terrestrial border and close economic relations. Sweden started revising its foreign policy vector in 1991. The governing elite had an active discussion which ended with a compromise decision on preserving the neutral status of the country alongside with enforcing its defensive capacities.

Since 1992, Finland and Sweden became participants of various agreements with NATO. Their armed forces and armaments systems have adopted the NATO standards, and have been working out their practical interaction during the joint military maneuvers and within Partnership for Peace program. In 2009 Nordic defense cooperation emerged, including three NATO participants - Iceland, Norway and Denmark. In April 2014 they signed an agreement on close military cooperation.

Results. We can state without any doubt that Finland and Sweden would join NATO only when they face a real threat towards themselves. Russian policy in the region can be a trigger for that. After Crimea annexed Russia, the amount of advocates of joining NATO increased. Nevertheless, they still remain a minority. In this situation a referendum on joining NATO appears to have no perspectives. On the contrary, we should $\infty$ mark that both countries became involved into "crawling" integration into NATO structures: alongside with $\underset{\sim}{*}$ official Partnership for Peace program it takes place in the official European integration institutions. After joining the EU in 1995 Sweden and Finland are obliged to obey the joint European security and foreign policies, i.e. arranging their military and foreign policies with basic principles and directives developed jointly with other EU members, who are also participants of NATO. Thus, neutrality of these two states becomes a phantom, especially towards Russia.

Key words: neutrality, non-alignment policy, finlandization, preventive diplomacy, NATO, EU.

Citation. Boldyreva S.Yu., Boldyrev R.Yu. Political Discussions on Admission of Neutral Countries of the Arctic Region to NATO in the 1990s - 2000s: Inclusion or a Limited Neutrality? Vestnik Volgogradskogo gosudarstvennogo universiteta. Seriya 4, Istoriya. Regionovedenie. Mezhdunarodnye otnosheniya [Science Journal of Volgograd State University. History. Area Studies. International Relations], 2018, vol. 23, no. 6, pp. 146-153. DOI: https://doi.org/10.15688/jvolsu4.2018.6.11
\end{abstract}




\title{
ПОЛИТИЧЕСКИЕ ДИСКУССИИ ВОКРУГ ВСТУПЛЕНИЯ НЕЙТРАЛЬНЫХ СТРАН АРКТИЧЕСКОГО РЕГИОНА В НАТО В 1990-2000-е ГГ.: ВКЛЮЧЕНИЕ ИЛИ ОГРАНИЧЕННЫЙ НЕЙТРАЛИТЕТ?
}

\author{
Славяна Юрьевна Болдырева \\ Северный (Арктический) федеральный университет им. М.В. Ломоносова, \\ г. Архангельск, Российская Федерация \\ Роман Юрьевич Болдырев \\ Северный (Арктический) федеральный университет им. М.В. Ломоносова, \\ г. Архангельск, Российская Федерация
}

\begin{abstract}
Аннотация. В статье авторами затрагивается проблема взаимоотношений НАТО и нейтральных государств Северной Европы (Швеции и Финляндии) в 1990-2000-е гг., которая исследуется в контексте евроатлантической безопасности. В работе подчеркивается, что Финляндия и Швеция обладают весьма высоким рейтингом стратегической привлекательности для НАТО. Впервые дается систематизация этапов эволюции взаимоотношений Организации Североатлантического договора и внеблоковых стран Северной Европы, рассматриваются тенденции сотрудничества между ними, а также предпосылки, перспективы и возможные последствия членства Швеции и Финляндии в НАТО. Большое внимание уделяется эволюции нейтралитета этих стран в сторону его большей ограниченности в условиях вхождения обеих стран в Европейский союз.

С.Ю. Болдыревой проанализирована эволюция финского нейтралитета в 1990-2000-е гг., изменение характера взаимоотношений Финляндии с Россией и Североатлантическим альянсом. Р.Ю. Болдыревым дан анализ шведской внешней политики на атлантическом и балтийском направлении, раскрыты причины, этапы и особенности сближения Швеции с НАТО.

Ключевые слова: нейтралитет, политика неприсоединения, «финляндизация», превентивная дипломатия, НАTO, ЕС.

Цитирование. Болдырева С. Ю., Болдырев Р. Ю. Политические дискуссии вокруг вступления нейтральных стран Арктического региона в НАТО в 1990-2000-е гг.: включение или ограниченный нейтралитет? // Вестник Волгоградского государственного университета. Серия 4, История. Регионоведение. Международные отношения. - 2018. - Т. 23, № 6. - С. 146-153. - (На англ.). - DOI: https://doi.org/10.15688/jvolsu4.2018.6.11
\end{abstract}

Introduction. Two Nordic countries played a special role in the mechanism of NATO interaction with neutral countries: Sweden and Finland. Both states have a very important military and strategic position: Sweden stretches along the most part of the Baltic Sea western shores, connecting territories of Denmark and Norway, controlling the straight leading from Baltic Sea to Northern Sea; Finland stretches on $1265 \mathrm{~km}$ from the south to the north along the Russian border controlling the northern shore of the Gulf of Finland. Without the member status in NATO both states have always been extremely active in collaboration within Alliance activities, being defacto its outpost on the northern borders of Russia.

The purpose of the paper is to analyze the background and perspectives of merging Sweden and Finland into NATO in the 1990s - 2000s. The issue of admitting Sweden and Finland into the Alliance appeared on the top of the agenda after both states had entered the European Union in 1995 and acceptance of the neighboring Baltic states into NATO in 2004. As a result, firstly, Sweden and Finland became surrounded by territories of NATO member states on three from four sides; secondly, general security and foreign policies of the EU were integrated into the united defensive system of the European allies of the USA and Canada.

There is a common opinion in Russian political thought that "the main stability condition in the North of Europe is a non-participation policy of Sweden and Finland in the military alliances" [5, p. 71]. Such position limits approach towards 
an objective analysis of Swedish and Finnish policy in this aspect. Over the last years, especially after Crimea annexed Russia, a vast number of critical publications on the possible integration of Sweden and Finland into NATO has appeared in Russian media. Nevertheless, in general the issue of perspective merging of Sweden and Finland into NATO remains a subject to discussion that makes this paper relevant.

Discussion. Discussion on the admission of Sweden and Finland into NATO began in the 1990s. After reunification of Germany in the autumn of 1990 Finnish government declared that the articles of peace treaty signed in 1947 on the obligations of Finland in repelling the German aggression have ceased to be in force. Besides, Finland stopped to consider itself limited by military and technical limitations outcoming from the treaty. On January 20, 1992 Russian Federation and Finland signed a treaty replacing the treaty on friendship, cooperation and mutual assistance between Finland and the USSR from April 6, 1948 [23]. According to a new agreement, Finland does not have any obstacles to conclude political or military alliances with the third parties [14, p. 206]. Afterwards it turned clear, which third party it appears to be: already in May 1992 Finnish Prime Minister Esko Aho in his speech made an accent on the historical significance of NATO as a guarantor of security for Denmark and Norway [8, p. 360].

Nevertheless, an official position of these countries towards the Alliance remains based on the non-alignment policy towards military blocs due to geopolitical factors: firstly, due to territorial proximity, and, as a result, special sensitivity towards the position of Russia.

Analysis. Closure of Swedish and Finnish interests also became possible due to a task of NATO to reconcile crisis cases and to develop partnership networks with other countries. It correlated with the main tasks of foreign policy of Finland and Sweden, which paid significant attention to preventive diplomacy. In 1992 both countries joined the North Atlantic Cooperation Council as the observers, which later evolved into Euro-Atlantic Partnership Council, and also entered the Partnership for Peace programme [15]. Finland and Sweden took part in the operation of NATO contingent operation in compliance with the Dayton agreements on Bosnia, later replaced by SFOR ${ }^{1}$. Both countries also contributed to involvement of Russia and the Baltic states into "Partnership for Peace" framework activities. On the contrary to Sweden, Finland lobbies interests of Russia more actively, in the aforementioned programme framework in particular, being more interested in stable relations with its eastern neighbor.

With formation of the government under Carl Bildt chairmanship in 1991 a purpose for revision of Swedish foreign policy became a subject for discussion: a question of preserving the traditional neutrality in foreign policy appeared in agenda. Carl Bildt himself alongside with ruling Christian Democratic party (Kristdemokraterna) and the People's party - Liberals (Folkpartietbiberalerna) supposed, that the country should abandon its neutral status. As a main argument stated by defense minister Anders Björck was an issue of supporting the defense capacity of Sweden in conditions of governmental course aimed to decline the military expenses [12].

A compromise reached in the late 1990s inside Swedish political elite was expressed in "preserving the principle of non-alignment of the country to military alliances with a purpose to provide it with a possibility to keep its neutrality in case of a war breakout" [10]. In the end of 1995 Riksdag confirmed that neutrality and high defense capacity are set in stone principles of Swedish foreign policy. New foreign affairs minister Anna Lindh during her speech in the Swedish institute of international relations stated that neutrality of the country still assists in achieving security in the Baltic sea area.

Nevertheless, Swedish armed forces cooperate with NATO actively, participating in joint military exercises and military operations. We should also take into consideration an economic aspect: Swedish army requires significant financing, covering $1,7 \%$ GDP of the country. Due to that, numerous Swedish politicians consider NATO membership as a possibility to solve defense capacity financial issues.

A special role of Sweden in relationship with NATO appears in the form of Nordic defense cooperation, created in 2009 and including Denmark, Iceland and Norway alongside with Sweden and Finland. Without NATO membership Sweden provides Nordic defense cooperation members with armament supplies and also participates in reforming armed forces of these 
states according to NATO standards. In 2014 Sweden criticized merging Crimea into Russia and joined the anti-Russian sanctions. In April 2014 Sweden, Norway, Finland, Denmark and Iceland have signed a document on tense military cooperation. Some of analysts have called it 'An Atlantic mini-NATO'. Sweden and Finland have simultaneously launched remilitarization of Gotland ${ }^{2}$ and Åland islands ${ }^{3}$. Numerous politicians connect the decision with Ukrainian crisis and Crimea annexing. In May 2016 Sweden ratified a cooperation agreement with NATO allowing its troops to participate in exercises taking place on Swedish territory. Furthermore, in case war breaks out in the region, Swedes will permit NATO to set up military bases on their territory.

In Finland discussion on joining NATO appeared in political agenda in the end of the 1980s. The fact can be connected, firstly, with an issue of positioning the country in Europe after the collapse of the USSR and new identity search [17]. The number of NATO partnership advocates is rather low, though arguments regarding that are active. A motive for that was a NATO expansion towards east, which started in the 1990s and was connected with the reunification of Germany and downfall of communist regimes in Central and Eastern Europe. One of the most active advocates of Finnish NATO membership is, for example, a well-known Finnish diplomat and political observer Max Jacobson, who supposed that accession of Poland, Czechia and Hungary to NATO in 1999 changed the balance of powers in Europe and led to revision of Swedish and Finnish neutrality [19]. He also states that Finns are unsettled by worsening relations with Russia due to including Baltic region countries into NATO and breaking stability in Northern Europe. According to his opinion, Russia is interested in preserving its domination in the Baltic area in any case, despite any possible position towards accession to NATO in Sweden and Finland. Therefore, it is irrational to set a position of Finland into a dependence on possible reaction of the country, which cannot be influenced by Russian government. Moreover, "if NATO remains a European security guarantor, neutrality of Sweden and Finland sets them into a status of secondary players in accepting the decisions on European security" [7].

Nevertheless, despite the discussion on NATO accession in Finnish society, a governmental official course remains unchanged: Finland still does not join any military and political blocs, NATO membership is considered only as a remote perspective. In a governmental report "Security in changing world" published in 1995 it was stated that "Finland will continue its nonalignment policy towards military alliances within changes occurring in Europe. Finland managed to create a reliable defensive capacities with an international recognition basing on its own resources" [21]. Military leaders constantly underline that defense capacities of the country is the most reliable guarantor of avoiding war, despite a character of any crisis occurring [21]. Alignment to NATO is not a recognized need since most of Finnish politicians suppose that the country does not need any security guarantees from the alliance. On the contrary, alignment of Finland to NATO could have changed the situation with jeopardizing stability in the region.

There is a small-numbered group of politicians in Finland, who are advocates of alignment to NATO. Originally it used to be a small "Young Finns" party (Nuorsuomalaiset) under leadership of Risto Pentilä. Besides them, former head of the EU military committee and also Finnish defense minister general Gustav Hägglund also actively supported alignment of Finland to NATO [15]. In 2004 he even presented an idea of turning the joint EU defense policy into "a European base" of NATO. In that case the "American base" of NATO could be involved into worldwide operations against terrorism, and the "European base" could participate in a crisis management in the region [5]. A Finnish Scholar Kristen Pursiainen has presented an interesting statement. Alignment of Finland to NATO is required due to "an indirect support of an idea, that EU and Russia are enemies" finding advocates in the country despite its neutral status. According to his opinion, NATO membership of Finland could give the country new possibilities of integrating Russia into western institutions: "Without NATO membership, Finland also remains outside developing relations between NATO and Russia, and thus cannot influence on a vast number of factors directly connected with its security" [5]. Nevertheless, an official position of Helsinki is based on the non-alignment policy towards military alliances. 
A well-known Finnish politician, one of participants of President elections in 2018 Matti Vanhanen greeted the partnership with NATO alongside with discussion on tense cooperation of Finland and NATO, but he stated that it will not lead to joining the alliance [13]. President of Finland Sauli Niinistö alongside with a former foreign affairs minister Alexander Stubb actively promote the idea of alignment to NATO. Alexander Stubb in one of his interviews in 2014 stated: "Despite the fact, that I am an advocate of NATO membership for my country, I am not sure that it is the moment for it. We should also consider, that only $25 \%$ of Finns agree with it" [6]. President of Finland Sauli Niinistö supposes that the best moment for joining NATO was in the beginning of the 1990s, but it was lost. At the same moment, Foreign minister of Finland in 2011-2015 Erkki Tuomioja has given an equivocal assessment to perspectives of joining NATO: "As it is stated in governmental programme, Finland is not a member of the Alliance, but cooperates with NATO and preserves a possibility to apply for a membership" [3].

Advocates of NATO membership name the following reasons for it: firstly, it is security of the country, thus even with losing some part of its sovereignty it is more acceptable to look for a protection from a stronger political player. According to the opinion of numerous Finns, terrorism and imperial ambitions of Russia jeopardize the international security. Secondly, NATO membership can increase status and significance of the country. Though the authors of collective monograph "Northern Europe - a region of new development" suppose that on the contrary, NATO expansion with alignment of Sweden and Finland can have their role in EU institutions decrease dramatically. Also, a regional and sub-regional cooperation frameworks can suffer, mostly with Russia [4, pp. 418-440].

The political establishment of Finland also has people criticizing the possible NATO membership, who supposes that it can turn the country into a comfortable staging ground for military infrastructure in a close proximity to Russian borders. Numerous Finnish politicians state that the organization wants the countries without membership to participate in crisis operations more actively alongside with accompanying decision-making procedures, so it could help the alliance to acquire more soldiers for complicated missions. A former ambassador of Finland in Russia Heikki Talvitie stated that NATO membership could have not enforce security of Finland, because the western powers are not interested in defending the Finnish territory. A hypothetic amount of assistance provided from NATO and preparedness of its members to send it are up in the air. Therefore for Finland it could be a careless step to initiate a confrontation with Russia having such dubious guarantees from NATO. Heikki Talvite did not doubt in a profit from NATO membership to Finland, but warned against forcing the process and complicating the situation on Russian border at the time [20].

Meanwhile Finland appears to be prepared for NATO membership: armed forces and armament systems are reformed according to NATO standards, practical interaction skills increased during the joint military exercises and Partnership for Peace programme. Finland ordered from the USA various types of missiles and supplementary hardware for them costing \$277 million overall, willing to confirm its positive relations with alliance [3]. Admiral Juhani Kaskeala stated that Finnish army is absolutely prepared to join NATO. This statement of former commander in chief in 2001-2009 confirms that non-alignment to military blocs does not mean that the country will remain neutral [23].

When conducting its foreign and defense policies, both states base on a purpose to support its relations with NATO in order to support stability in Baltic sea area: "NATO is the only international organization, which is able to maintain crisis management requiring military intervention and military operations and pacification by force operations", and "expansion of... NATO has increased the security level in territories, which are in a proximity from Finland" [1]. Numerous Swedish politicians underline that there is no European power to dominate in Northern Europe, and the US presence appears to be a counterweight towards such possibility. Also both countries greet various "non-military" cooperation within NATO like minimizing harm towards ecological balance caused by military activities, holding the peacekeeping operations and emergency recovery [17]. "Partnership for peace" programme obtains a special status having a cooperation core in "increasing the operative 
compatibility of the armed forces of the participating countries with a purpose to establish successful operative frameworks" [16]. It is crucial to underline the fact, that operations coordinated by the Alliance with participation of the partner countries are recognized as primary in European crisis management, though the EU and its joint foreign policy and CFSP ${ }^{4}$ also remain a crucial instrument in security policy.

Transatlantic solidarity support grew especially in the beginning of the 2000s in Sweden and Finland after the events of September 11, 2001. Finnish and Swedish foreign ministers have announced: "If an EU member state subjects to terrorist attack, both Sweden and Finland will provide any relevant assistance" [9]. Both countries have also made practical steps in this area, offering to improve the Euro-Atlantic Partnership Council functions to reply the threat. Nevertheless, Helsinki and Stockholm do not suppose any alternative of NATO to be established in order to hold anti-terrorist activities.

We can be sure that Finland and Sweden join NATO only when they face a real jeopardy, not a mythic one. In the beginning of the 1990s Swedish foreign minister Margaretha af Ugglas stated that non-alignment policy is a mean, not a final aim [18]. This is a final point since Swedish politicians have not make any step further yet. Despite the statements from conservatives in Moderate coalitional party (Moderatasamlingspartiet) and Liberal party (Liberalerna) supporting the alignment of Sweden to NATO, the government holds its own line.

Social democrat Erkki Tuomioja who occupied foreign minister position between 2011 and 2015 states that Finland should increase its military cooperation with Sweden. One of cooperation issues is unification of air and maritime defense of both countries [2]. Numerous politicians of Sweden and Finland announce openly that military cooperation of both countries is a main priority in defense policy for them. Though it is careless to speak about a new military bloc, but Swedish - Finnish interaction can definitely lead to creating an treaty-based alliance.

A Russian policy in the region can trigger this process. Swedish commander in chief, general Micael Byden ${ }^{5}$ has openly stated that possibility to launch a conflict between NATO and Russia in the Baltic sea area increased. During his visit to Lithuania he emphasizes that arrival of NATO military equipment to the region at the moment, when Russia demonstrates its wish to use military forces for achieving political objectives increases the risks of conflict and provocations [2].

Swedish defense ministry studies the legal aftermath of signing this kind of treaty with Finland at the moment. This attempt to create a de-jure military bloc has gained political support in both states. So, an ex-defense minister of Finland Matti Vanhanen is sure, that creating an alliance can turn into a main component of establishing a state security of both countries on a higher level: "I support this point of view, according to which we should be extremely careful in war and peace issues. We cannot be sure, that in emergency case we can receive resources from our neighbor, if we still recognize a cooperation with Sweden as a voluntary one. A defensive alliance between two countries cannot be in force functionally or even possible, unless we make our joint foreign policy. Only in this case a true alliance of two national states can be put into force" [2]. A bilateral agreement and a defensive alliance could make grounds for overcoming various indefinite situations in the future and also define joint resource application frameworks, according to his opinion.

Allan Widman, chairman of Swedish Riksdag defense committee supposes that the Swedish government should at first clarify the long-lasting perspective of Swedish-Finnish cooperation. The party, where he is a member, the Liberal party (Liberalerna) in general supports the creating of legally formed military alliance, recognizing it as the first step towards possible NATO membership. The Moderate coalitional party (Moderatasamlingspartiet) also supports this initiative, also requiring the Swedish government to create a road map of Swedish alignment to NATO. The Moderaterna suppose, that those amendments, which were offered to be made in the Treaty between Sweden and NATO in 2014 still leave the kingdom isolated, unprotected and lacking the defense guarantees from NATO, that the Alliance provides any assistance. The Treaty allowed NATO to relocate troops through the Swedish territory, but only when peace is in force. An emphasis is set there on participation of NATO forces in exercises hosted in Sweden. At the moment, Sweden is considering amendments to the document, which could allow the NATO 
forces to relocate through Swedish territory not only within peaceful case, but also during the armed conflict situation.

Nevertheless 2/3 of citizens in Finland and Sweden suppose that both countries should solve their defense issues on their own. At the same time, 1/4 of respondents are advocates of joint policy in defense issues [3]. According to the opinion of Swedish experts, grounds of such phenomenon are not connected with doubting towards position of Finland, but in skepticism towards any military alliance in general. It can also refer to Finland as well.

This conclusion is circumstantially confirmed with an attitude towards NATO. More than a half of survey participants are convicted that cooperation with NATO should not be extended. Almost the same number of respondents have such attitude in Sweden. $40 \%$ of respondents support enforcing the cooperation between NATO and their country [3]. Sociologists noticed that the number of NATO alignment advocates grew after Crimea had merged Russia, though still remaining a minority. The Atlantists appear predominantly within some separate parties or as a "private opinion". A Center party (Centerpartiet) offers to revise the national neutrality. Nevertheless, the political elite of both countries shows a reserved position in this case.

In case Finland and Sweden having a high level of military preparedness align to NATO, it changes the military and political balance in the Baltic region in particular, and in whole Northern Europe in general. The contact line between NATO and Russia in this case lasts through the whole Northern Europe from the Barents Sea to Pskov and Kaliningrad [23].

It should force Russia to develop several scenarios of its policy towards Baltic states and NATO, to plan the issue of guarantees of its own security, also on a mutually beneficial basis for the whole region [22]. It can be traced via regular joint state visits of presidents of Russia and Finland. When considering the Baltic states alignment to NATO, and its proximity to Saint Petersburg, we come to a conclusion that the Finnish factor becomes a decisive one for providing the security of Northwestern Russia, for a free exit from the Gulf of Finland, for connection with the Kaliningrad region and the Atlantic ocean without obstacles and for gas delivery lines construction on the bottom of the Baltic sea.

President of Russia Vladimir Putin commented a possible alignment to NATO of one of the neighbours of the country - Finland: "In various political and social groups of Finland this issue appears from time to time. Our attitude towards extending the military and political alliances in general, and towards NATO in particular is well-known, and we do not think that it will assist in supporting the security level in the world. Finland is a full member of the Western community, and an EU member. Approaching the NATO infrastructure to Russian borders via Finland will not assist in improving relations between our countries. But the main thing is that the contemporary threats are mainly in struggle against terror, drug traffic, human trade, organized criminal, mass destruction weapon and delivery means dissemination. These problems can be solved only with joint efforts an on a bloc-free basis. As far as I know, the Finnish government supports this point of view. Nevertheless, the final decision is in the hands of the Finnish people, and Finnish government" [11].

An ex-prime minister of Finland, and also a candidate during the presidential elections in 2018, Matti Vanhanen supposes that alignment of Finland to NATO could be a "genuine choice", even despite the fact of increasing the risks for Russia. According to his opinion, interest of Finland towards NATO membership was provoked by actions taken by Russia and its aggressive conduct in the region. Present-day foreign minister of Finland Timo Soini emphasizes a crucial character of joing security policy for the EU, but a possibility to join NATO at any moment should become a background for the country.

Results. Thus, attitudes of Sweden and Finland towards NATO base on three opportunities: the first one is a military nonalignment as an option, which can be also abandoned in a future. The second, when Helsinki and Stockholm show their will to involve into planning and implementing decisions where it is possible in a maximum level of their abilities. The main difference between positions of these two countries is that Finland is actively attempting to involve Russia into joint military exercises within NATO vector. Also Finland is a more active initiator and participant of various NATO 
programmes. It is connected with position of Sweden as an independent player between major powers, while Finland recognized itself as a small country in the Baltic sea region, whose position had a disrespectful label of "Finlandization". Thirdly, these Northern European countries constantly emphasize the importance of crisis management and preventive diplomacy as a counterweight towards direct military force of NATO.

At the moment, holding a referendum with alignment to NATO as a subject has no perspectives since the majority of population will vote against this decision. Also putting their armies to NATO standards will cause the increase of expenditures, which can also gain a negative reply.

We should also consider that both counties became involved into "creeping" NATO integration: it takes place via both official Partnership for Peace programme and official European institutions. Becoming EU members in 1995, Sweden and Finland have obligations to follow the joint European security and foreign policies via arranging their military and foreign policy vectors with basic principles and joining directives developed in a partnership with other EU members, who are also simultaneously NATO members. It means, that the neutrality of both Nordic countries becomes a phantom, especially towards the Russian Federation.

\section{NOTES}

${ }^{1}$ Stabilization Force. According to Dayton agreements signed on 21 November 1995 a NATO military contingent entered the territory of Bosnia and Herzegovina - Implementation Force (IFOR). SFOR mission was established according to the UN Security Council resolution No. 1088 of 12 November 1996 as a mission-successor of IFOR.

${ }^{2}$ Between 2005 and 2016 regular troops were not stationed on the Gotland island. In September 2016 a military exercise took place there with the participation of 150 soldiers of mounted infantry, who have received an order to be stationed there on a regular basis.

${ }^{3}$ According to Eland Convention of 1921 signed by ten states (Sweden, Finland, Germany, Great Britain, France, Italy, Denmark, Poland, Estonia and Latvia) and ratified by the League of Nations, Eland islands are totally neutralized and demilitarized zone - no military units can be stationed there, and no military fortifications can be established.
${ }^{4}$ Common Foreign and Security Policy (CFSP).

${ }^{5}$ Commander in chief of Swedish armed forces (Swedish: Цverbefдlhavaren) is the highest rank officer in Swedish military hierarchy, according to NATO terms, this position is an equivalent to Swedish chief of defense term.

\section{REFERENCES}

1. Boldyreva E.L. Strategiya ministerstva oborony Finlyandii "Bezopasno v budushchee" [Strategy of the Ministry of Defense of Finland 'Safe Way to the Future']. Mezhdunarodnye otnosheniya $i$ dialog kultur, 2012, no. 1, pp. 27-31.

2. Bondina V. Finlyandiya i Shvetsiya mogut sozdat voennyy soyuz: protiv kogo? [Finland and Sweden Can Establish a Military Union: against Whom?]. URL: http://gpolitika.com/evropa/ finlyandiya-i-shveciya-mogut-sozdat-voennyj-soyuzprotiv-kogo.html (accessed 26 May 2018).

3. Budut li Shvetsiya i Finlyandiya v NATO? [Will Sweden and Finland Join NATO?]. URL: https:// topwar.ru/33690-budut-li-shveciya-i-finlyandiya-vnato.html (accessed 26 May 2018).

4. Deryabin Yu.S., Antyushina N.M., eds. Severnaya Evropa. Region novogo razvitiya [Northern Europe: The Region of New Development]. Moscow, Ves mir Publ., 2008. 512 p.

5. Deryabin Yu.S. Vse li tak spokoyno na severe Evropy? [Is Everyting so Still in Northern Europe?]. Sovremennaya Evropa, 2003, no. 4, pp. 68-79.

6. Ermolaeva N. Finlyandiya ne budet vstupat v NATO [Finland Will Not Enter NATO]. Rossiyskaya gazeta, 2014, September 30. URL: https://rg.ru/2014/09/30/finlandiya-site-anons.html (accessed 26 May 2018).

7. Jakobson M. Strakhovka po-finski [Finnish Insurance]. URL: http://www.rg.ru/2004/02/20/ finlyandiya.html (accessed 26 May 2018).

8. Jussila O., Hentilд S., Nevakivi J. Politicheskaya istoriya Finlyandii [Political History of Finland]. Moscow, Ves mir Publ., 1998. 384 p.

9. Kantokoski O.A. Sotrudnichestvo stran Skandinavii $i$ Finlyandii $v$ sfere borby $s$ mezhdunarodnym terrorizmom [Cooperation of Scandinavian Countries and Finland in Struggle against International Terrorism]. URL: http:// www.kunstkamera.ru/lib/rubrikator/03/03 05/978-588431-162-6/ (accessed 26 May 2018).

10. Kuchinskaya M.E. Kuda idut byvshie "evroneytraly" (na primere Shvetsii i Finlyandii) [Where Are Going Former "European Neutrals" (the Case of Sweden and Finland)]. URL: https://riss.ru/ images/pdf/journal/2012/6/10_.pdf (accessed 26 May 2018). 
11. Latukhina K. Putin predupredil o posledstviyakh vstupleniya Finlyandii v NATO [Putin Alerted Finland to Consequences of Entry into NATO]. URL: https://rg.ru/2016/07/01/putin-predupredil-oposledstviiah-vstupleniia-finliandii-v-nato.html (accessed 26 May 2018).

12. Malmqvist H. Shvetsiya i NATO: 23 goda spustya [Sweden and NATO - 23 down the Road]. URL: https://www.nato.int/docu/Review/2018/ Also-in-2018/sweden-and-nato-23-years-downthe-road-defence-security/RU/index.htm (accessed 26 May 2018).

13. Malyshkin A. RF v koltse "druzey": Shvetsiya $i$ Finlyandiya zadumalis o chlenstve $v$ NATO [The Russian Federation in the Circle of "Friends": Sweden and Finland Think about NATO Membership]. URL: https://ria.ru/world/20140903/ 1022627620.html (accessed 26 May 2018).

14. Meinander H. History of Finland. Moscow, Ves mir Publ., 2006. 248 p.

15. NATO gotovit neozhidannyy «udar»v Evrope [NATO Prepares “Jerk" in Europe]. URL: https:/ /www.pravda.ru/world/europe/european/22-08-2008/ 280291-nato-0/ (accessed 26 May 2018).

16. Petrov V., Ognev A. Programma NATO "Partnerstvo radi mira" [NATO Program Partnership for Peace]. URL: http://factmil.com/publ/strana/ avstrija/programma_nato_partnjorstvo_radi_ mira_2013/54-1-0-351 (accessed 26 May 2018).

17. Pogodin S.N. Mezhdunarodnaya deyatelnost Finlyandii v sfere bezopasnosti [International Activity of Finland in the Security Sphere]. Mezhdunarodnye otnosheniya i dialog kultur, 2012, no. 1, pp. 8-26.
18. Poplavskiy A. Formirovanie politiki bezopasnosti Norvegii i Shvetsii v 1990-e gg. [Developing the Security Policy of Norway and Sweden in the 1990s]. Belorusskiy zhurnal mezhdunarodnogo prava i mezhdunarodnykh otnosheniy, 2003, no. 4. URL: http://www.evolutio.info/content/view/907/215/ (accessed 26 May 2018).

19. Rebro O. Oboronnaya politika Finlyandii $i$ Shvetsii: perspektivy vstupleniya $v$ NATO [Defense Policies of Finland and Sweden: NATO Alignment Perspectives]. URL: http://www.foreignpolicy.ru/ analyses/oboronnaya-politika-finlyandii-i-shvetsiiperpektivy-vstupleniya-v-nato/ (accessed 26 May 2018).

20. U Finlyandii net neobkhodimosti vstupat $v$ NATO "iz printsipa" ("Keskisuomalainen", Finlyandiya) [Finland Does Not Principally Need to Align NATO ('Keskisuomalainen', Finland)]. URL: http://apn-nn.com/90527-510357.html (accessed 26 May 2018).

21. Voronkov L.S. Svobodnye ot voennykh soyuzov Shvetsiya i Finlyandiya i NATO [Free from Military Alliances Sweden and Finland and NATO]. URL: https://interaffairs.ru/news/show/17125 (accessed 26 May 2018).

22. Zharskiy A.P., Korshunov E.L. Severnye sosedi: proshchay neytralitet [Northern Neighbors: Goodbye, Neutrality]. Voenno-promyshlennyy kuryer, 2010, no. 8. URL: https://vpk-news.ru/articles/5540 (accessed 26 May 2018).

23. Zharskiy A.P., Korshunov E.L. Voennaya politika gosudarstv Severnoy Evropy [Military Policy of the North European States]. Zashchita $i$ bezopasnost, 2009, no. 2, pp. 34-36.

\section{Information about the Authors}

Slavyana Yu. Boldyreva, Candidate of Sciences (History), Associate Professor of Department of Area Studies, International Relations and Political Science, Northern (Arctic) Federal University named after M.V. Lomonosov, Naberezhnaya Severnoy Dviny, 17, 163002 Arkhangelsk, Russian Federation, s.boldyreva@narfu.ru,https://orcid.org/0000-0003-0677-6312

Roman Yu. Boldyrev, Candidate of Sciences (History), Associate Professor of Department of World History, Northern (Arctic) Federal University named after M.V. Lomonosov, Naberezhnaya Severnoy Dviny, 17, 163002 Arkhangelsk, Russian Federation, r.boldyrev@narfu.ru, https://orcid.org/0000-0003-4262-7285

\section{Информация об авторах}

Славяна Юрьевна Болдырева, кандидат исторических наук, доцент кафедры регионоведения, международных отношений и политологии, Северный (Арктический) федеральный университет им. М.В Ломоносова, наб. Северной Двины, 17, 163002 г. Архангельск, Российская Федерация, s.boldyreva@narfu.ru, https://orcid.org/0000-0003-0677-6312

Роман Юрьевич Болдырев, кандидат исторических наук, доцент кафедры всеобщей истории, Северный (Арктический) федеральный университет им. М.В. Ломоносова, наб. Северной Двины, 17, 163002 г. Архангельск, Российская Федерация, r.boldyrev@narfu.ru, https://orcid.org/0000-0003-4262-7285 